\title{
Chromosomal Instability in Streptomyces glaucescens: Mapping of Streptomycin-sensitive Mutants
}

\author{
By RETO CRAMERI, TOBIAS KIESER, $\dagger$ HIDEO ONO, \\ JESUS SANCHEZ§ AND RALF HÜTTER* \\ Mikrobiologisches Institut, Eidgenössische Technische Hochschule, ETH-Zentrum, \\ CH-8092 Zürich, Switzerland
}

(Received 24 May 1982; revised 30 August 1982)

\begin{abstract}
Streptomyces glaucescens strain GLA0 (=ETH 22794) produces hydroxystreptomycin and has a high natural resistance to hydroxystreptomycin, dihydrostreptomycin and streptomycin. The wild-type strain gives rise spontaneously to streptomycin-sensitive $\left(\mathrm{StrS}^{-}\right)$variants at a frequency of 0.2 to $1.4 \%$. These mutants lack streptomycin phosphotransferase activity responsible for the wild-type resistance to streptomycin group antibiotics and are unable to produce detectable amounts of hydroxystreptomycin.

Mapping experiments showed that the str $S$ marker lies between the chromosomal markers lys-2 and ura-3 on the linkage map of $S$. glaucescens. The molecular basis for instability of this marker is as yet unknown.
\end{abstract}

\section{INTRODUCTION}

Genetic instability is a widespread phenomenon among streptomycetes. The most thoroughly investigated unstable characters are natural resistance to antibiotics (Freeman et al., 1977; Freeman \& Hopwood, 1978; Sermonti et al., 1977, 1978, 1980; Fedorenko \& Danilenko, 1980; Kirby \& Lewis, 1981), aerial mycelium formation (Pogell, 1979; Redshaw et al., 1979), production of pigments (Gregory \& Huang, 1964a, b; Pogell, 1979; Hütter et al., 1981; Schrempf, 1981) and the production of antibiotics (Shaw \& Piwowarski, 1977; Kirby, 1978; Schrempf, 1981).

An extensive genetic analysis is available only for chloramphenicol resistance in Streptomyces coelicolor A3(2) (Freeman et al., 1977; Sermonti et al., 1977, 1978, 1980) and for erythromycin resistance in the same strain (Puzynina et al., 1979). Chloramphenicol sensitivity was found to be reversible and no constant map position for the resistance gene could be established (Freeman et al., 1977). According to Sermonti et al. (1980) two chromosomal map positions may be deduced from crossing data and the authors therefore deduced that a jumping gene might be responsible for chloramphenicol resistance in this strain. However, the interpretation of the data may be questioned (Lanfaloni et al., 1980).

In the case of erythromycin resistance the marker was found to segregate chromosomally and the authors postulated, that erythromycin sensitivity is caused by transposition of genetic material (Puzynina et al., 1979). In both cases, chloramphenicol and erythromycin resistance, no data about the resistance mechanism were published.

Similarly, Streptomyces glaucescens possesses a natural resistance towards streptomycin group aminoglycoside antibiotics, but the resistance is highly unstable. Streptomycin-sensitive variants arise with high frequency spontaneously after induction by curing agents or after other

† Present address: John Innes Institute, Colney Lane, Norwich NR4 7UH, U.K.

$\ddagger$ Present address: Takeda Chemical Ind., Central Research Division, Jusohonmachi 2, Yodogawa-ku, Osaka 532, Japan.

$\S$ Present address: Departemento Interfacultativo de Microbiologia, Universidad de Oviedo, Oviedo, Spain. 
Table 1. Streptomyces glaucescens strains

\begin{tabular}{|c|c|c|c|}
\hline Strain & Genetic markers* & $\begin{array}{l}\text { Status of } \\
\text { streptomycin } \\
\text { resistance } \dagger\end{array}$ & $\begin{array}{l}\text { Mutagenic } \\
\text { treatment }\end{array}$ \\
\hline GLA0 & Wild-type & str $S^{+}$ & - \\
\hline GLA15 & ura-3 met-2 & $\operatorname{str} S^{+}$ & - \\
\hline GLA20 & gua-4 lys-1 & str $S^{+}$ & - \\
\hline GLA21 & hom-1 lys-1 & str $S^{+}$ & - \\
\hline GLA23 & lys -2 ura -5 & $s t r S^{+}$ & 一 \\
\hline GLA24 & $t h r-1$ lys-2 & strS $S-24$ & NTG (GLA31) \\
\hline GLA31 & $l y s-2$ & $s t r S^{+}$ & - \\
\hline GLA46 & $t h r-1$ & strS-24 & - \\
\hline GLA58 & nic-2 & $s t r S^{+}$ & - \\
\hline GLA62 & lys-2 ura-3 & $\operatorname{str} S^{+}$ & 一 \\
\hline GLA65 & ura-5 met-2 & str $S^{+}$ & - \\
\hline GLA71 & pro- 1 ade- 1 & str $S^{+}$ & - \\
\hline GLA72 & lys-2 ade-1 & $\operatorname{str} S^{+}$ & - \\
\hline GLA75 & leu-2 ura-2 ade-1 & str $S^{+}$ & - \\
\hline GLA84 & lys-2 pro-1 & str $S^{+}$ & - \\
\hline GLA128 & rif-565 met-8 & strS- 128 & EB (GLA565) \\
\hline GLA205 & Prototroph & strS-205 & CS (GLA0) \\
\hline GLA207 & Prototroph & strS-207 & AO (GLA0) \\
\hline GLA212 & Prototroph & strS-212 & EB (GLA0) \\
\hline GLA512 & $h i s-2$ & strS $S^{+}$ & - \\
\hline GLA516 & nic-2 ura-3 & str $S^{+}$ & - \\
\hline GLA528 & lys-3 leu-2 & strS $S^{+}$ & - \\
\hline GLA541 & ura-3 nic-2 & strS-541 & EB (GLA516) \\
\hline GLA543 & lys-2 ade-I & strS-543 & Spontaneous (GLA72) \\
\hline GLA544 & nic-2 & strS-544 & EB (GLA 58) \\
\hline GLA547 & ura-2 nic-2 rif-547 & $s t r S^{+}$ & - \\
\hline GLA565 & met -8 rif- 565 & str $S^{+}$ & - \\
\hline GLA567 & met -8 rif-567 & $s t r S^{+}$ & - \\
\hline GLA572 & lys -2 thi-3 rif-572 & str $S^{+}$ & - \\
\hline GLA 877 & rif-567 pro- 1 ade- 1 & str $S^{+}$ & - \\
\hline
\end{tabular}

* Marker designations are according to Demerec et al. (1966) (see also Baumann et al., 1974 and Hütter et al., 1981).

† Two loci determining the degree of streptomycin resistance are distinguished (Hütter et al., 1981). The wildtype strain GLA0 $\operatorname{str} \mathrm{A}^{+} \operatorname{str} \mathrm{S}^{+}$can grow on agar media containing up to $10 \mathrm{mg}$ streptomycin $\mathrm{1}^{-1}$. Strains carrying the mutant allele $s t r A^{-4}\left(s t r S^{+}\right.$or $s t r S$ ) exhibit a high streptomycin resistance (growth on media with $\geqslant 100 \mathrm{mg}$ streptomycin $\mathrm{l}^{-1}$ ), while $s t r A^{+}$str $S$ strains are highly streptomycin sensitive (minimal inhibitory concentration $0.2 \mathrm{mg}$ streptomycin $\mathrm{1}^{-1}$ ). All strains used had the genotype $\operatorname{str} A^{+}$.

$\ddagger$ NTG, $N$-methyl- $N^{\prime}$-nitro- $N$-nitrosoguanidine; EB, ethidium bromide; CS, cold storage; AO, acridine orange. The strain numbers in parentheses designate the direct parent of the corresponding mutant strain. - , Designates mutational and recombinational derivatives from the stock culture collection.

mutagenic treatments (Freeman \& Hopwood, 1978; Suter et al., 1978; Hütter et al., 1981). The natural streptomycin resistance observed in the wild-type strain is due to the presence of a streptomycin phosphotransferase. Sensitive mutant strains lack this enzyme. Simultaneously they lose the capacity to produce detectable amounts of hydroxystreptomycin, indicating either the participation of the phosphotransferase both in antibiotic production and antibiotic resistance or the presence of multiple gene defects in strS mutant strains (Ono et al., 1983).

In this paper we report on the genetic analysis of the streptomycin-sensitive mutants. A preliminary report of the data was given in Hütter et al. (1981).

\section{METHODS}

Strains. All mutant strains used are derivatives of Streptomyces glaucescens strain GLA0 (corresponding to strain ETH 22794, Baumann et al., 1974; Hütter et al., 1981) and are listed in Table 1. The linkage map of the markers used is given in Fig. 1. 
Table 2. Isolation of streptomycin-sensitive colonies from the wild-type and from mutant strains of Streptomyces glaucescens

Strain $\begin{gathered}\text { No. of } \\ \text { colonies tested } *\end{gathered} \overbrace{\text { Total } \%}^{\text {StrS isolates }}$

(a) Spontaneously occurring StrS mutants

\begin{tabular}{|c|c|c|c|}
\hline GLA0 & 1856 & 8 & 0.43 \\
\hline GLA15 & 757 & 5 & 0.66 \\
\hline GLA20 & 218 & 0 & - \\
\hline GLA21 & 280 & 0 & - \\
\hline GLA23 & 134 & 1 & 0.75 \\
\hline GLA62 & 700 & 0 & - \\
\hline GLA65 & 700 & 0 & - \\
\hline GLA71 & 2514 & 0 & - \\
\hline GLA72 & 822 & 3 & 0.36 \\
\hline GLA75 & 558 & 8 & 1.43 \\
\hline GLA84 & 650 & 0 & - \\
\hline GLA512 & 337 & 0 & - \\
\hline GLA516 & 1800 & 0 & - \\
\hline GLA528 & 170 & 0 & - \\
\hline GLA547 & 880 & 2 & 0.23 \\
\hline GLA567 & 1654 & 0 & - \\
\hline \multirow[t]{2}{*}{ GLA572 } & 1356 & 0 & - \\
\hline & & \multicolumn{2}{|c|}{ StrS isolates } \\
\hline Strain & $\begin{array}{c}\text { No. of } \\
\text { colonies tested } \dagger\end{array}$ & ta & $\%$ \\
\hline
\end{tabular}

(b) StrS mutants after growth on media containing ethidium bromide

$\begin{array}{lrrr}\text { GLA0 } & 9090 & 6819 & 75 \cdot 01 \\ \text { GLA65 } & 956 & 653 & 68 \cdot 30 \\ \text { GLA516 } & 1247 & 1156 & 92 \cdot 70\end{array}$

\begin{tabular}{|c|c|c|c|c|c|}
\hline \multirow[b]{2}{*}{ Strain } & \multirow{2}{*}{$\begin{array}{c}\text { No. of } \\
\text { colonies tested }\end{array}$} & \multicolumn{2}{|c|}{ Auxotrophic mutants } & \multicolumn{2}{|c|}{ StrS isolates } \\
\hline & & Total & $\%$ & Total & $\%$ \\
\hline \multicolumn{6}{|c|}{ (c) StrS mutants after $U V$ irradiation } \\
\hline GLA0 & 9658 & 64 & 0.66 & 17 & $0 \cdot 18$ \\
\hline GLA65 & 8899 & 58 & 0.65 & 27 & $0 \cdot 30$ \\
\hline GLA516 & 9223 & 49 & 0.53 & 3 & 0.03 \\
\hline & & \multicolumn{2}{|c|}{ Auxotrophic mutants } & \multicolumn{2}{|c|}{ StrS isolates } \\
\hline Strain & colonies tested & Total & $\%$ & Total & $\%$ \\
\hline
\end{tabular}

(d) StrS mutants after mutagenesis with $N$-methyl- $N^{\prime}$-nitro- $N$-nitrosoguanidine

$\begin{array}{llllll}\text { GLA0 } & 3856 & 34 & 0.88 & 11 & 0.29 \\ \text { GLA65 } & 5260 & 37 & 0.70 & 23 & 0.44 \\ \text { GLA516 } & 6941 & 59 & 0.85 & 35 & 0.50\end{array}$

* No spontaneous auxotrophic mutants could be detected (spontaneous mutant frequency $<10^{-4}$ )/

$\dagger$ Survivors on agar media containing $7 \mu \mathrm{mol}$ ethidium bromide $1^{-1}$. Auxotrophic mutants arose with frequencies $<10^{-4}$.

Cultural conditions. All chemicals were of analytical grade where possible. Strains were grown on yeast extract/malt extract agar (Difco) (Pridham et al., 1956/7) at $37^{\circ} \mathrm{C}$. Well sporulated cultures were usually stored at $4{ }^{\circ} \mathrm{C}$. Streptomycin-sensitive mutants, however, were cold-sensitive and lost their viability quickly at low temperatures; they were therefore stored at room temperature. For segregation analysis a minimal medium of the following composition was used: glucose, $10 \mathrm{~g} ; \mathrm{NaNO}_{3}, 0.3 \mathrm{~g} ; \mathrm{K}_{2} \mathrm{HPO}_{4}, 0.5 \mathrm{~g} ; \mathrm{CaCl}_{2}, 0.01 \mathrm{~g} ; \mathrm{MgSO}_{4} .7 \mathrm{H}_{2} \mathrm{O}$, $0.2 \mathrm{~g} ; \mathrm{FeSO}_{4} .7 \mathrm{H}_{2} \mathrm{O}, 0.01 \mathrm{~g} ; \mathrm{ZnSO}_{4} .7 \mathrm{H}_{2} \mathrm{O}, 0.01 \mathrm{~g} ; \mathrm{CuSO}_{4} .5 \mathrm{H}_{2} \mathrm{O}, 0.01 \mathrm{~g} ; \mathrm{MnSO}_{4} . \mathrm{H}_{2} \mathrm{O}, 0.04 \mathrm{~g} ;$ Bacto-Agar (Difco), $20 \mathrm{~g}$; deionized water to $1000 \mathrm{ml}, \mathrm{pH}$ adjusted to 7.5 with $1 \mathrm{~mol} \mathrm{HCl} 1^{-1}$ before autoclaving. Selective media were prepared from minimal medium by the addition of the necessary supplements at the following 
Table 3. Fertility of crosses involving StrS mutant strains

\begin{tabular}{|c|c|c|c|}
\hline \multirow[b]{2}{*}{ Parent strains* } & \multirow[b]{2}{*}{ Selection } & \multicolumn{2}{|c|}{$\begin{array}{l}\text { Fertility† with } \\
\text { respect to }\end{array}$} \\
\hline & & Parent 1 & Parent 2 \\
\hline $\begin{array}{l}\text { GLA72 } \times \text { GLA58 (control) } \\
\text { GLA72 } \times \text { GLA544 }\end{array}$ & $a d e^{+} n i c^{+}$ & $\begin{array}{l}8 \times 10^{-3} \\
4 \times 10^{-4}\end{array}$ & $\begin{array}{l}2 \times 10^{-3} \\
1 \times 10^{-3}\end{array}$ \\
\hline GLA541 $\times \overline{\text { GLA24 }}$ & $l y s^{+} n i c^{+}$ & $8 \times 10^{-3}$ & $5 \times 10^{-3}$ \\
\hline $\begin{array}{l}\overline{\text { GLA72 }} \times \overline{\text { GLA516 (control) }} \\
\text { GLA72 } \times \overline{\text { GLA541 }} \\
\underline{\text { GLA543 }} \times \underline{\text { GLA541 }}\end{array}$ & $a d e^{+} u r a^{+}$ & $\begin{array}{l}7 \times 10^{-5} \\
6 \times 10^{-5} \\
6 \times 10^{-6}\end{array}$ & $\begin{array}{l}7 \times 10^{-7} \\
3 \times 10^{-3} \\
6 \times 10^{-5}\end{array}$ \\
\hline
\end{tabular}

* StrS strains are underlined.

$\dagger$ Fertility defined as number of recombinant colonies per number of parental colonies.

concentrations: amino acids, $10^{-3} \mathrm{~mol} \mathrm{1} \mathrm{1}^{-1}$; purines and pyrimidines, $5 \times 10^{-4} \mathrm{~mol}^{-1}$; vitamins, $5 \times$ $10^{-5} \mathrm{~mol}^{-1}$. The wild-type strain is sensitive to $2 \mathrm{mg}$ rifampicin $\mathrm{1}^{-1}$ (Ciba-Geigy) and to $10 \mathrm{mg}$ streptomycin sulphate $\mathrm{l}^{-1}$ (Novo Industri, Copenhagen, Denmark). Rifamycin-resistant (Rifr) recombinants were selected with $100 \mathrm{mg}$ rifampicin $\mathrm{1}^{-1}, \mathrm{str} \mathrm{S}^{+}$recombinants with $2 \mathrm{mg}$ streptomycin $\mathrm{1}^{-1}$.

Genetic techniques. These were as described by Baumann et al. (1974).

Isolation of streptomycin-sensitive mutants. Streptomycin-sensitive mutants were isolated as clones unable to grow on agar media containing $2 \mathrm{mg}$ streptomycin $\mathrm{l}^{-1}$, after one of the following treatments: UV irradiation (dose $1.9 \mathrm{~mJ} \mathrm{~mm}^{-2}$ ), $N$-methyl- $N^{\prime}$-nitro- $N$-nitrosoguanidine (NTG) (Serva) mutagenesis (Delić et al., 1970), growth on yeast extract/malt extract agar containing 6 or $7 \mu$ mol ethidium bromide (EB) $1^{-1}$ (Serva) (Suter, 1978; Hütter $e t$ al., 1981) or acridine orange (Serva) at the same concentrations, or after cold storage (Suter et al., 1978). Sensitive colonies were routinely subcloned three times.

\section{RESULTS}

\section{Frequency of StrS mutant strains}

The wild-type strain and auxotrophic str $A^{+}$str $S^{+}$mutant strains of $S$. glaucescens can grow on agar media supplemented with up to $10 \mu \mathrm{g}$ streptomycin $\mathrm{ml}^{-1}$ (Hütter et al., 1981). Mutant derivatives more sensitive to streptomycin than the parent strain arise spontaneously at a frequency of approximately $0.2 \%$ (Freeman \& Hopwood, 1978; Hütter et al., 1981). These strains were designated StrS-types.

In a more detailed study the spontaneous frequency of StrS progeny was analysed in sixteen mutational and recombinational derivatives of $S$. glaucescens. Five of the strains investigated yielded streptomycin-sensitive variants with frequencies between 0.2 and $1.4 \%$ (Table $2 \mathrm{a}$ ). The frequency of auxotrophic mutations was below $10^{-4}$. UV irradiation or mutagenesis with NTG did not increase the frequency of StrS mutations in selected strains above the spontaneous frequency or above the frequency of induced auxotrophic mutations (Table 2c, d). However, growth on agar media containing EB yielded up to $90 \%$ StrS variants among the survivors with the wild-type strain and with all mutant strains tested (Table $2 b$ ).

All streptomycin-sensitive mutants were initially unstable and reverted phenotypically to wild-type resistance, but after successive recloning of single spore isolates no spontaneous reversion to $\mathrm{StrS}^{+}$was observed (reversion frequency $<10^{-9}$ ).

\section{Crosses between independent StrS derivatives}

Crosses between independently isolated streptomycin-sensitive strains $\left(\mathrm{StrS}^{-}\right)$never yielded recombinant colonies with wild-type streptomycin resistance (data not shown). The detection level of recombinant frequency was about $10^{-9}$. Crosses exhibited normal fertility with respect to chromosomal markers and no systematic influence on fertility was observed in crosses heterozygous for StrS (Table 3). 
Table 4. Analysis of a multi-factor cross of strains GLA516 ura-3, nic-2, strS $S^{+}$and GLA24 thr-1, lys-2, strS-24

\begin{tabular}{|c|c|c|c|c|c|c|c|c|c|}
\hline \multirow[b]{3}{*}{$t h r$} & & & & & \multicolumn{4}{|c|}{ Selection for } & \multirow{3}{*}{$\begin{array}{c}\text { Crossover in } \\
\text { intervals } \dagger\end{array}$} \\
\hline & \multicolumn{3}{|c|}{ Genotype* } & \multirow[b]{2}{*}{$s t r S$} & \multirow{2}{*}{$\begin{array}{l}\text { thr } \\
u r a^{+}\end{array}$} & \multirow{2}{*}{$\begin{array}{l}\text { thr } \\
n i c^{+}\end{array}$} & \multirow{2}{*}{$\begin{array}{l}\text { lys }^{+} \\
\text {ura }^{+}\end{array}$} & \multirow{2}{*}{$\begin{array}{l}\text { lys }^{+} \\
\text {nic }^{+}\end{array}$} & \\
\hline & lys & ura & nic & & & & & & \\
\hline+ & + & + & + & + & 18 & 25 & 18 & 30 & 2,4 \\
\hline+ & + & + & + & str $S$ & 57 & 78 & 36 & 72 & 2,4 \\
\hline+ & + & + & nic & + & 10 & - & 23 & - & 2,3 \\
\hline+ & + & + & nic & $\operatorname{str} S$ & 54 & - & 54 & - & 2,3 \\
\hline+ & + & ura & + & + & - & 21 & - & 23 & 3,4 \\
\hline+ & + & ura & + & strS & - & 9 & - & 7 & 3,4 \\
\hline+ & lys & + & + & + & 1 & 2 & - & - & 1,4 \\
\hline+ & lys & + & + & strS & 8 & 13 & - & - & 1,4 \\
\hline thr & + & + & + & + & - & - & 12 & 7 & 1,2 \\
\hline$t h r$ & + & + & + & strS & - & - & 5 & 12 & 1,2 \\
\hline \multirow[t]{2}{*}{ thr } & + & ura & + & + & - & - & - & 1 & 1,4 \\
\hline & & & & Total & 148 & 148 & 148 & 152 & \\
\hline
\end{tabular}

* + , Wild-type allele; strS, streptomycin sensitivity. $\dagger$ The str $S$ allele is not considered.
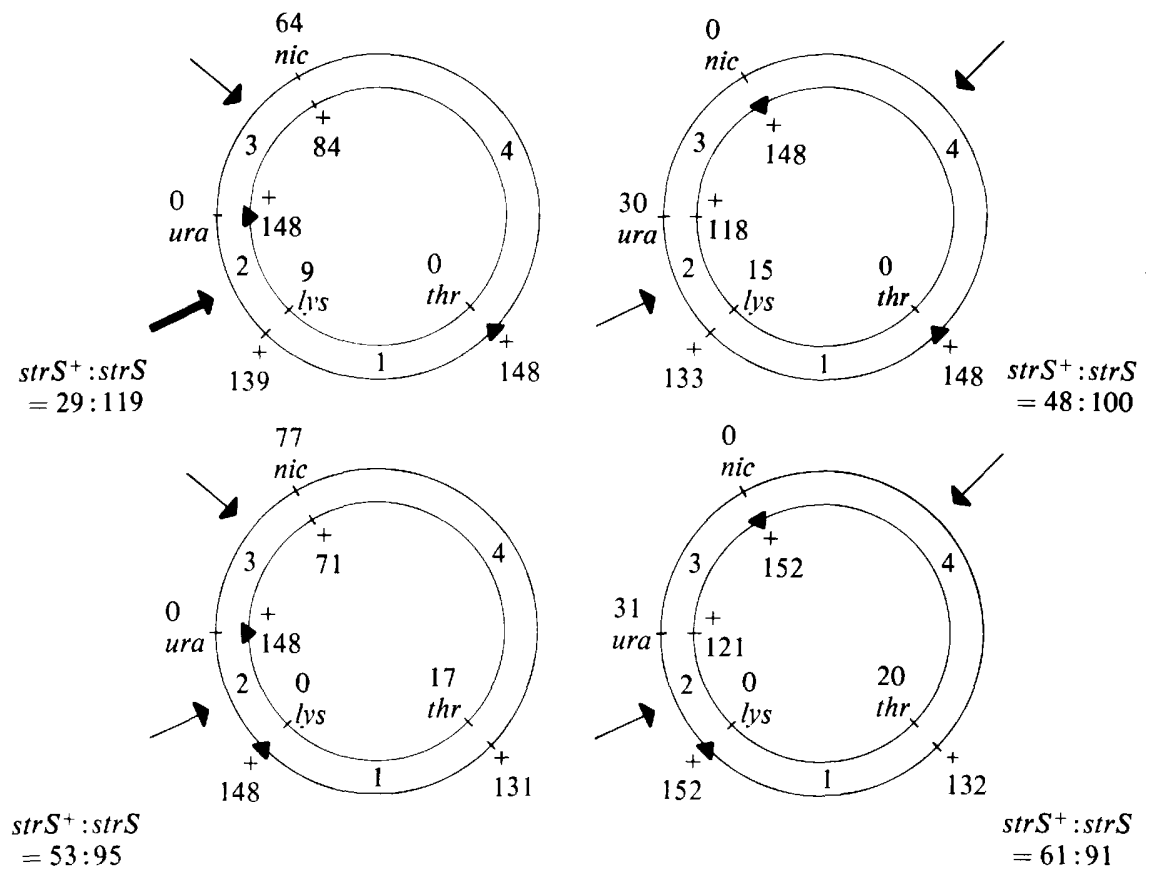

Marker frequencies based on the recombinant analysis are given. The two circles represent schematically the circular linkage map of the $s t r S^{+}$strain GLA516 (outer circle) and the $s t r S$ strain GLA24 (inner circle). Triangles in the diagram indicate selected alleles. The arrows designate possible locations of the $s t r S^{+}$allele as derived from marker frequencies. Thick arrows indicate the interval highly favoured by minimizing the number of multiple crossovers for placing the $s t r S^{+}$marker in this interval.

\section{Mapping of strS alleles}

Crosses were made primarily between strains carrying the $s t r S-24$ allele and multiply marked $s t r S^{+}$strains. Results were evaluated by tabulating the number of segregants carrying the $s t r S^{+}$ allele versus segregants carrying the $s t r S$ allele in relation to the non-selected markers. The map location was deduced by minimizing the number of required multiple crossovers and from the 
Table 5. Analysis of a multi-factor cross of strains GLA877 rif-567, pro-1, ade-1, strS ${ }^{+}$and GLA46 thr-1, strS-24

\begin{tabular}{|c|c|c|c|c|c|c|c|c|c|}
\hline \multirow[b]{3}{*}{ rif } & & & & \multirow[b]{3}{*}{ strS } & \multicolumn{4}{|c|}{ Selection for } & \multirow{3}{*}{$\begin{array}{c}\text { Crossover in } \\
\text { intervals } \dagger\end{array}$} \\
\hline & \multicolumn{3}{|c|}{ Genotype* } & & \multirow{2}{*}{$\begin{array}{c}\text { ade } e^{+} \\
t h r^{+}\end{array}$} & \multirow{2}{*}{$\begin{array}{l}\text { pro }^{+} \\
\text {thr }^{+}\end{array}$} & \multirow{2}{*}{$\begin{array}{c}\text { pro }^{+} \\
\text {rif }^{+}\end{array}$} & \multirow{2}{*}{$\begin{array}{c}a d e^{+} \\
\text {rif }^{+}\end{array}$} & \\
\hline & $t h r$ & pro & ade & & & & & & \\
\hline+ & + & + & + & + & 12 & 8 & - & - & 1,2 \\
\hline+ & + & + & + & strS & 11 & 15 & - & - & 1,2 \\
\hline rif & + & + & + & + & 18 & 15 & 21 & 29 & 2,4 \\
\hline rif & + & + & + & strS & 22 & 26 & 14 & 18 & 2,4 \\
\hline+ & + & pro & + & + & 1 & - & - & - & 1,3 \\
\hline rif & $t h r$ & + & + & + & 一 & 一 & 0 & 1 & 1,4 \\
\hline rif & thr & + & + & strS & - & - & 18 & 29 & 1,4 \\
\hline rif & + & pro & + & + & 10 & - & - & 14 & 3,4 \\
\hline rif & + & pro & + & strS & 1 & - & - & 0 & 3,4 \\
\hline rif & + & + & ade & + & - & 5 & 8 & - & 2,3 \\
\hline rif & + & + & ade & strS & - & 7 & 4 & - & 2,3 \\
\hline rif & $t h r$ & pro & + & + & - & - & - & 1 & $1,2,3,4$ \\
\hline rif & $t h r$ & + & ade & strS & - & - & 12 & - & 1,3 \\
\hline & & & & Total & 75 & 76 & 77 & 92 & \\
\hline
\end{tabular}

* + , Wild-type allele; rif, rifamycin resistance.

+ The $s t r S$ allele is not considered.
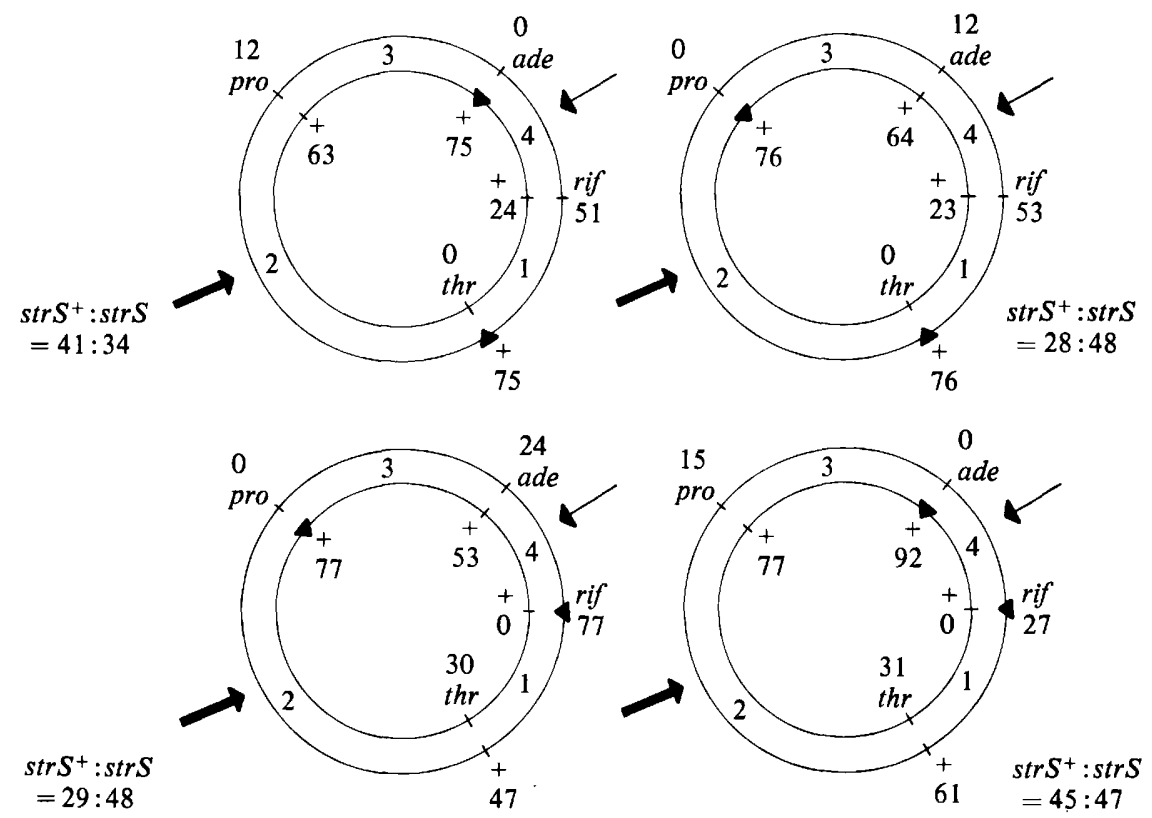

The two circles represent the circular linkage map of the $s t r S^{+}$strain GLA877 (outer circle) and the strS strain GLA46 (inner circle). For further details of arrangement see Table 4.

marker gradient. In all cases a chromosomal location of the strS marker in the region between lys-2 and ura-3 on the linkage map of $S$. glaucescens was found. Two examples of crosses are presented in Tables 4 and 5 . The map position of the $s t r S-24$ allele was confirmed by the results of several additional crosses (data not shown).

The segregation of the strS alleles present in other mutant strains (GLA128, GLA205, GLA207, GLA212, GLA541, GLA543 and GLA544, see Table 1) obtained after various mutagenic treatments was analysed by crossing these strains with the multiply marked $s t r S^{+}$ 


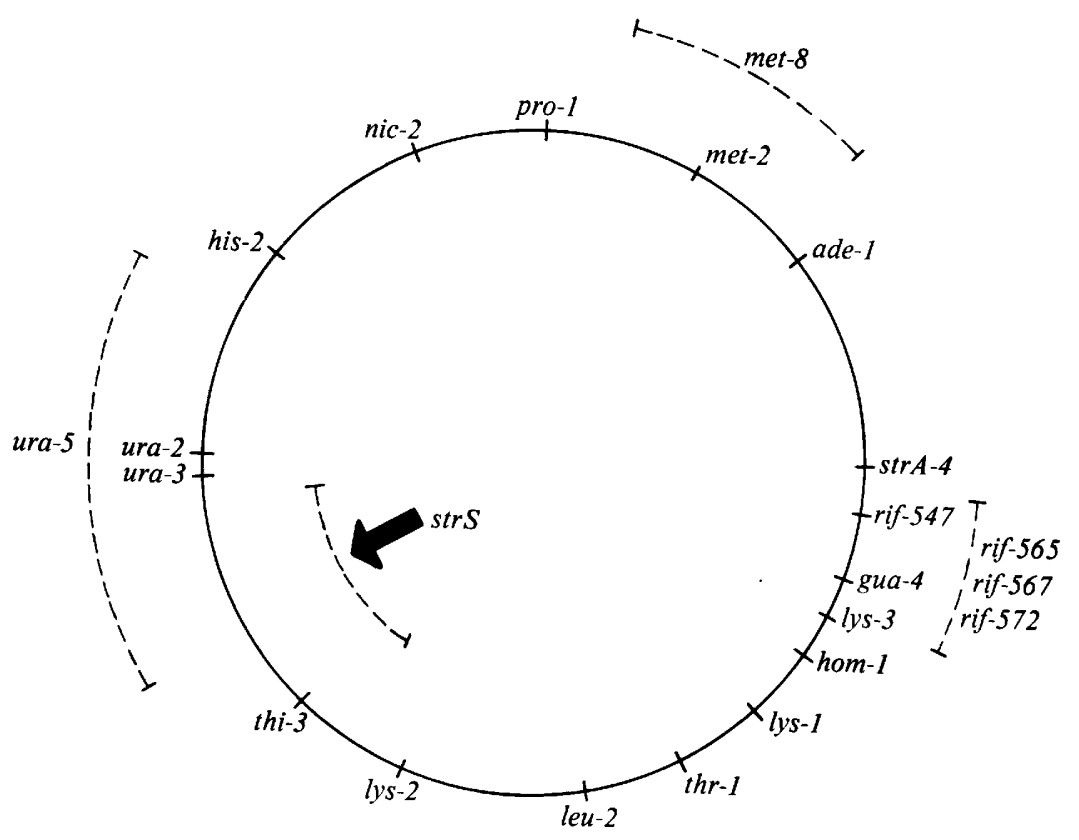

Fig. 1. Linkage map of Streptomyces glaucescens. The linkage map shown is according to Baumann et al. (1974) and Hütter et al. (1981). Only the markers used in this work are shown (see Table 1); ---- uncertain map position in this region.

strains previously mentioned. The results obtained were comparable to those obtained with the str $\mathrm{S}-24$ allele (data not shown). All these crosses showed normal recombination frequencies for chromosomal markers (see above).

\section{DISCUSSION}

Streptomyces glaucescens strain GLA0 produces hydroxystreptomycin and is naturally resistant to this antibiotic and the related compounds streptomycin and dihydrostreptomycin. Streptomycin sensitive ( $\mathrm{StrS}^{-}$) strains arose spontaneously with frequencies between 0.2 and $1.4 \%$. All StrS- isolates had lost hydroxystreptomycin production as well (Ono et al., 1983). The frequency of $\mathrm{StrS}^{-}$strains could be increased to up to $90 \%$ by growth of colonies derived from single spores on agar media containing EB. Notably, the frequency of $\mathrm{StrS}^{-}$strains was not increased above the level of other chromosomal mutations by UV irradiation which is known to increase the frequency of plasmid loss in other streptomycetes (Friend et al., 1978; Hopwood, 1978). Freshly isolated $\mathrm{StrS}^{-}$strains did revert to the wild-type resistance level at a frequency of about $10^{-5}$ (Freeman \& Hopwood, 1978). After two or three steps of subculturing, however, stable $\mathrm{StrS}^{-}$strains were usually isolated $\left(<10^{-9}\right.$ revertants in spore suspensions). The basis of stability after successive recloning is not yet understood. The high spontaneous frequency of $\mathrm{StrS}^{-}$strains and the increase in frequency after EB treatment suggested the possible involvement of an unstable extrachromosomal genetic element involved in hydroxystreptomycin biosynthesis and resistance. This hypothesis was supported by the observation, that crosses between independent, stable StrS- ${ }^{-}$strains never led to recombinant progeny with the wild-type level of streptomycin resistance. Controls showed that the absence of $\mathrm{StrS}^{+}$recombinant progeny was not due to sterility in these crosses.

Despite numerous attempts, no plasmid DNA could be isolated from strain GLA0 nor any of its derivatives. Genetic mapping, however, indicated a unique chromosomal location for the str $S$ mutation on the circular linkage map of $S$. glaucescens between the $l y s-2$ and the ura- 3 
markers (Fig. 1). All strS mutant strains tested lacked hydroxystreptomycin 6-phosphotransferase activity, while cell free extracts of strain GLA0 effectively inactivate streptomycins in an ATP-dependent reaction (Ono et al., 1983).

Two interpretations are likely for our data. It is conceivable that the phosphotransferase is necessary to hydroxystreptomycin production (see Ono et al., 1983). This could account for the concomitant loss of both antibiotic resistance and production. Another possibility is, that the $s t r S$ mutation affects several genes either due to polarity or to a large deletion. Although unlikely, it is still possible, that these genes are coded on a stable plasmid, which is dependent on an unstable chromosomal gene for its maintenance. Additional investigations at the DNA level are required to uncover the molecular basis of the genetic instability at the $s t r S^{+}$site.

We thank M. Zatchej for competent technical help. These studies were supported by a research grant from the Swiss Federal Institute of Technology, Zürich.

\section{REFERENCES}

Baumann, R., Hütter, R. \& Hopwood, D. A. (1974). Genetic analysis in a melanin-producing streptomycete: Streptomyces glaucescens. Journal of General Microbiology 81, 463-474.

Delić, V., HoPwOOD, D. A. \& FrIEND, E. J. (1970). Mutagenesis by $N$-methyl- $N^{\prime}$-nitro- $N$-nitrosoguanidine (NTG) in Streptomyces coelicolor. Mutation Research 9, 167-182.

Demerec, M., Adelberg, A., Clark, A. J. \& Hartman, P. E. (1966). A proposal for a uniform nomenclature in bacterial genetics. Genetics 54, 6176.

FEDORENKo, V. A. \& DANILENKo, V. N. (1980). Instability of natural multiple drug resistance in actinomycetes. Antibiotiki 25, 170-174.

Freeman, R. F. \& Hopwood, D. A. (1978). Unstable naturally occurring resistance to antibiotics in Streptomyces. Journal of General Microbiology 106, 377-381.

Freeman, R. F., BibB, M. J. \& Hopwood, D. A. (1977). Chloramphenicol acetyltransferase-independent chloramphenicol resistance in Streptomyces coelicolor A3(2). Journal of General Microbiology 98, 453465.

Friend, E. J., WARREN, M. \& HoPWOOD, D. A. (1978). Genetic evidence for a plasmid controlling fertility in an industrial strain of Streptomyces rimosus. Journal of General Microbiology 106, 201-206.

Gregory, K. F. \& HuANG, J. C. C. (1964a). Tyrosinase inheritance in Streptomyces scabies. I. Genetic recombination. Journal of Bacteriology 87 , 1281-1286.

Gregory, K. F. \& HuANG, J. C. C. (1964b). Tyrosinase inheritance in Streptomyces scabies. II. Induction of tyrosinase deficiency by acridine dyes. Journal of Bacteriology 87, 1287-1294.

Hopwood, D. A. (1978). Extrachromosomally determined antibiotic production. Annual Review of Microbiology 32, 373-392.

HütTER, R., Kieser, T., Crameri, R. \& HintermanN, G. (1981). Chromosomal instability in Streptomyces glaucescens. Zentralblatt für Bakteriologie, Mikrobiologie und Hygiene (supplement) 11, 551-559.

KIRBY, R. (1978). An unstable element affecting the production of the antibiotic holomycin by Streptomyces clavuligerus. FEMS Microbiology Letters 3, 283-286.
KIRBY, R. \& LEWIS, E. (1981). Unstable genetic elements affecting streptomycin resistance in the streptomycin-producing organisms Streptomyces griseus NCIB 8506 and Streptomyces bikiniensis ISP 5235. Journal of General Microbiology 122, 351355.

Lanfaloni, L., Micheli, M. R. \& Sermonti, G. (1980). "Salto" del transposone SCTnI su un plasmide in Streptomyces coelicolor. Rivista di biologia 73, 431-433.

Ono, H., Crameri, R., Hintermann, G. \& Hütter, R. (1983). Hydroxystreptomycin production and resistance in Streptomyces glaucescens. Journal of General Microbiology 129, 529-537.

PoGell, B. A. (1979). Regulation of aerial mycelium formation in streptomycetes. In Proceedings of the 3rd International Symposium on Genetics of Industrial Microorganisms, pp. 218-224. Edited by O. K. Sebek \& A. I. Laskin. Washington, D.C.: American Society for Microbiology.

Pridham, T. G., Anderson, P., Foley, C., LindenFELSER, L. A., Hesseltine, C. W. \& Benedict, R. G. (1956/7). A selection of media for maintenance and taxonomic study of Streptomyces. Antibiotics Annual 947-953.

Puzynina, G. G., Danilenko, V. N., Vasil'chenko, L. G., Mkrtumian, N. M. \& Lomovskaya, N. D. (1979). Determination of the erythromycin resistance of Streptomyces coelicolor A3(2). Genetika 15, 1151-1157 (English translation).

Redshaw, P. A., McCann, P. A., Pentella, M. A. \& Pogell, B. M. (1979). Simultaneous loss of multiple differentiated functions in aerial mycelium-negative isolates of streptomycetes. Journal of Bacteriology 137, 891-899.

SCHREMPF, H. (1981). Function of plasmid genes in streptomycetes. Zentralblatt für Bakteriologie, Mikrobiologie und Hygiene (supplement) 11, 545550 .

Sermonti, G., Petris, A., Micheli, R. \& Lanfaloni, L. (1977). A factor involved in chloramphenicol resistance in Streptomyces coelicolor A3(2): its transfer in the absence of the fertility factor. Journal of General Microbiology 100, 347-353.

Sermonti, G., Petris, A., Micheli, R. \& Lanfaloni, L. (1978). Chloramphenicol resistance in Streptomyces coelicolor A3(2): possible involvement of a 
transposable element. Molecular and General Genetics 164, 99-103.

Sermonti, G., LANFaloni, L. \& Micheli, R. (1980). A jumping gene in Streptomyces coelicolor A3(2). Molecular and General Genetics 177, 453-458.

Shaw, P. D. \& Piwowarski, J. (1977). Effects of ethidium bromide and acriflavine on streptomycin production by Streptomyces bikiniensis. Journal of Antibiotics 30, 404-408.

SUTER, M. A. (1978). Isolierung und Charakterisierung von Melanin-negativen Mutanten aus Streptomyces glaucescens. Thesis no. 6276, Eidgenössische Technische Hochschule Zürich, Switzerland.

Suter, M., HütTER, R. \& Leisinger, Th. (1978). Mutants of Streptomyces glaucescens affected in the production of extracellular enzymes. In Genetics of the Actinomycetales, pp. 61-64. Edited by E. Freerksen, I. Tarnok \& J. H. Thumin. Stuttgart \& New York: Gustav Fischer Verlag. 